\section{One-time vs. Continuous Application of Paclobutrazol in Subirrigation Water for the Production of Bedding Plants}

\author{
J.B. Million, J.E. Barrett ${ }^{1}$, T.A. Nell, and D.G. Clark \\ Department of Environmental Horticulture, University of Florida, Gainesville, \\ FL 32611-0670
}

Additional index words. Begonia $\times$ semperflorens-cultorum, Dendranthema $\times$ grandiflorum, ebb and flow, growth regulator, growth retardant, Impatiens wallerana, Petunia $\times$ hybrida

\begin{abstract}
Experiments were conducted with four kinds of flowering plants to compare one-time vs. continuous application of paclobutrazol in subirrigation water. When a crop reached the stage at which it required growth regulator treatment, four concentrations of paclobutrazol were applied via subirrigation either one-time or continuously until the crop was terminated. Based upon regression equations, concentrations resulting in $30 \%$ size reduction for one-time applications of paclobutrazol were $0.01 \mathrm{mg} \cdot \mathrm{L}^{-1}$ for Begonia $\times$ semperflorens-cultorum 'Cocktail Gin', $0.09 \mathrm{mg} \cdot \mathrm{L}^{-1}$ for Impatiens wallerana Hook. 'Super Elfin White', $0.2 \mathrm{mg} \cdot \mathrm{L}^{-1}$ for Dendranthema $\times$ grandiflorum (Ramat.) Kitamura 'Tara', and $2.4 \mathrm{mg} \cdot \mathrm{L}^{-1}$ for Petunia $\times$ hybrida Vilm.-Andr. 'Plum Crazy'. Respective optimal values for continuous application were $0.005,0.02,0.06$, and 0.4 $\mathrm{mg} \cdot \mathrm{L}^{-1}$. Increasing the concentration for continuous application had a greater effect on paclobutrazol efficacy than did increasing the concentration for a single application. In a trial with impatiens 'Super Elfin Salmon Blush', the paclobutrazol concentration was reduced $0 \%, 25 \%, 50 \%, 75 \%$, or $100 \%$ (single application) for each successive subirrigation event following an initial application of $0.1 \mathrm{mg} \cdot \mathbf{L}^{-1}$ of paclobutrazol. The $50 \%, 75 \%$, and $100 \%$ reduction treatments provided similar levels of size control. Dilution was more important when the reduction rate was less than $50 \%$. Chemical name

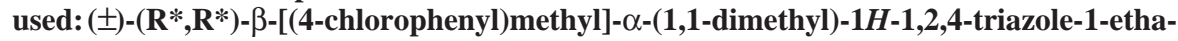
nol (paclobutrazol).
\end{abstract}

Careful attention to application rates is required when applying paclobutrazol to growing media because of its relatively high activity when absorbed by plant roots. Methods of applying paclobutrazol to growing media include drenching media with uniform volumes (Barrett, 1982), incorporating tablets or spikes into media (Newman and Tant, 1995; Sanderson et al., 1988), or injecting the chemical into drip irrigation or subirrigation water (Adriansen, 1989; Million et al., 1999).

One potential problem of applying paclobutrazol in subirrigation water is nonuniform uptake of solution volume. Differences in uptake volume during a one-time subirrigation application could result in large differences in chemical application rates. Continuous application of paclobutrazol at lower concentrations may provide a means for applying paclobutrazol in a more uniform or predictable manner.

Another potential problem of a one-time application of paclobutrazol in subirrigation water is the consequential effect of residual chemical in the subirrigation water. The de-

\footnotetext{
Received for publication 26 June 2000. Accepted for publication 10 Apr. 2001. Florida Agricultural Experiment Station Journal Series no. R-08019.

${ }^{1}$ To whom requests for reprints should be addressed. E-mail address: jbarrett@mail.ifas.ufl.edu
}

gree of dilution between subirrigation events should be an important factor in determining the consequential effect of residual chemical in the subirrigation system.

The objectives of this study were to compare one-time vs. continuous application of paclobutrazol in subirrigation solutions to several flowering crops and to evaluate the effect of dilution between successive subirrigation applications on the response of a flowering crop to paclobutrazol supplied in subirrigation solutions.

\section{Materials and Methods}

Expt. 1. One-time vs. continuous application. Plugs of begonia 'Cocktail Gin', impatiens 'Super Elfin White', and petunia 'Plum Crazy' were planted one per 10.2-cm (370$\mathrm{mL}$ ) pot on 10 Oct. 1996, 10 Oct. 1996, and 15 Jan. 1997, respectively. Chrysanthemum 'Tara' was planted one rooted cutting per 10.2-cm pot on 8 Jan. 1997. All pots were filled with Fafard No. 2 (Fafard, Anderson, S.C.), a peat-based growing medium that does not contain pine bark. Average daily minimum/maximum greenhouse temperatures were $19 / 30^{\circ} \mathrm{C}$ for begonia, $19 / 30{ }^{\circ} \mathrm{C}$ for impatiens, $18 / 28^{\circ} \mathrm{C}$ for petunia, and $18 / 30^{\circ} \mathrm{C}$ for chrysanthemum. On 15 Jan., chrysanthemums were soft-pinched and short-day $(8 \mathrm{~h}$ daylight) conditions were imposed. All four crops were subirrigated throughout the trial. To facilitate subirrigation, pots were kept in open-webbed flats which were lowered into trays $(25.4 \times 50.8 \times 5.1 \mathrm{~cm})$ filled $2.5-\mathrm{cm}$ deep with fertilizer solution. Pots were allowed to soak up solutions for 15-20 min. After each subirrigation, the open-webbed flats were lifted out of the solution and placed back on the bench. Fertilizer (20N-4.4P$16.6 \mathrm{~K}$ with minor elements; Scotts Co., Atlanta, Ga.) solution concentrations used throughout the trial were $\mathrm{N}$ at $75 \mathrm{mg} \cdot \mathrm{L}^{-1}$ for begonia and impatiens, $\mathrm{N}$ at $100 \mathrm{mg} \cdot \mathrm{L}^{-1}$ for petunia, and $\mathrm{N}$ at $150 \mathrm{mg} \cdot \mathrm{L}^{-1}$ for chrysanthemums.

Paclobutrazol subirrigation treatments were initiated on 25 Oct. for begonias, 22 Oct. for impatiens, and $31 \mathrm{Jan}$. for both petunias and chrysanthemums. Plants were subirrigated every other day for the first week and daily thereafter. Treatment solutions applied to each crop consisted of four paclobutrazol concentrations applied at a frequency of either once or continuously until the end of the crop. The four paclobutrazol concentrations were $0.001,0.003,0.01$, and $0.03 \mathrm{mg} \cdot \mathrm{L}^{-1}$ for begonia, $0.01,0.03,0.1$, and $0.3 \mathrm{mg} \cdot \mathrm{L}^{-1}$ for impatiens and chrysanthemums, and $0.3,1,3$, and $10 \mathrm{mg} \cdot \mathrm{L}^{-1}$ for petunia. The rates chosen were based upon earlier subirrigation research (Million et al., 1999) and relative crop sensitivities to drench applications. A nontreated control was also included for each crop. All treatment solutions were prepared in the respective fertilizer solutions described previously. For the initial treatment application only, uptake volume per pot was determined by weighing before and after the subirrigation soak.

Each experiment (crop) was arranged in a randomized block design with three blocks, nine treatments, and six plants per treatment within each block. Plant height above the pot rim and two perpendicular plant width measurements were taken at the time of treatment. Final measurements were taken on $12 \mathrm{Nov}$. for begonia, 5 Nov. for impatiens, 3 Mar. for petunia, and 13 Mar. for chrysanthemum. Size was calculated as (height + average width)/ 2 . Change in size was calculated as the final size minus the size at initial treatment. A relative change in size parameter was then calculated by dividing each observation by the mean value of the control treatment. An exponential decay curve (Little and Hills, 1978) was fitted to the relative change in size parameter data using a nonlinear regression procedure (PROC NLIN, SAS Institute, Cary, N.C.).

Expt. 2. Concentration reduction effect. On 15 Jan. 1997, impatiens 'Super Elfin Salmon Blush' were planted one plug per $10.2-\mathrm{cm}$ pot filled with Fafard No. 2. Plants were subirrigated as described for impatiens in Expt. 1. Six subirrigation paclobutrazol treatments were initiated on $31 \mathrm{Jan}$. Except for an untreated control, all treatments received an initial paclobutrazol application of $0.1 \mathrm{mg} \cdot \mathrm{L}^{-1}$ in the subirrigation water. After the initial application, each treatment concentration was reduced $0 \%, 25 \%, 50 \%, 75 \%$, or $100 \%$ between successive subirrigations. For 
example, the $0 \%$ reduction treatment consisted of a constant paclobutrazol application of $0.1 \mathrm{mg} \cdot \mathrm{L}^{-1}$, the $50 \%$ reduction treatment consisted of a halving of paclobutrazol concentration for each successive subirrigation, and the $100 \%$ reduction treatment consisted of a one-time application. As in Expt. 1, all subirrigation treatments were made up in fertilizer solutions. Plants were subirrigated every other day for the first week and daily thereafter. Initial size (Expt. 1) data were taken on 31 Jan. and final size data on $14 \mathrm{Feb}$. The experimental design was a randomized complete-block design with three blocks, six treatments, and six plants per treatment within each block.

\section{Results and Discussion}

Expt. 1. One-time vs. continuous. Mean plant height, width, and size of the untreated control at the time of first treatment were: 7 , 12 , and $10 \mathrm{~cm}$ for begonia; 5,14 , and $10 \mathrm{~cm}$ for impatiens; 7,12 , and $10 \mathrm{~cm}$ for chrysanthemum; and 2, 10, and $6 \mathrm{~cm}$ for petunia. Mean plant height, width, and size of the untreated control at the end of the experiment were: 12 , 25 , and $18 \mathrm{~cm}$ for begonia; 9,27 , and $18 \mathrm{~cm}$ for impatiens; 19,28 , and $24 \mathrm{~cm}$ for chrysanthemum; and 14, 30, and $22 \mathrm{~cm}$ for petunia.

An interaction $(P<0.0001)$ between paclobutrazol concentration and application frequency was observed for each crop. Therefore, regression curves are presented separately for each application frequency (Fig. 1). For each crop, the decay constant "c" in the regression equation $\mathrm{y}=\mathrm{a}+\mathrm{be}^{(-\mathrm{cx})}$ was greater for continuous application than for one-time application. This indicates that the rate of plant size reduction due to increasing paclobutrazol concentration was greater when the chemical was applied continuously than when it was applied one-time.

In order to compare directly the responses of the four crops tested, a $30 \%$ size reduction was selected as a reasonable level of size control. The optimal level of size reduction for any given crop varies depending upon variety, fertility, environment, irrigation frequency, crop duration, shipping size limitations, and other cultural practices, but we have found $20 \%$ to $40 \%$ to be typical for our conditions in Florida. Based upon the regression equations, $30 \%$ size reduction was achieved for begonia with a one-time application of $0.011 \mathrm{mg} \cdot \mathrm{L}^{-1}$ or continuous application of $0.005 \mathrm{mg} \cdot \mathrm{L}^{-1}$; respective values $\left(\mathrm{mg} \cdot \mathrm{L}^{-1}\right)$ were 0.087 and 0.022 for impatiens, 0.19 and 0.063 for chrysanthemum, and 2.3 and 0.42 for petunia. The optimal concentrations for continuous application were similar to those reported by Million et al. (1999). In that study, 20\% size reductions for begonia, impatiens, chrysanthemum, and petunia were achieved at concentrations of $0.005,0.017,0.024$, and $0.39 \mathrm{mg} \cdot \mathrm{L}^{-1}$, respectively. However, paclobutrazol treatments were applied throughout production in the earlier study, while in the present study, paclobutrazol treatments were applied during the last several weeks only. The same relative sensitivity of these crops to foliar paclobutrazol sprays has been reported (Barrett and Erwin, 1994).

The difference in paclobutrazol concentration required using continuous vs. onetime application in subirrigation water is of practical interest. By comparing the values required to achieve acceptable size reduction by the two methods, it follows that 2.1, 4.0, 5.4, and 3.0 times higher concentrations were required with a one-time application than with continuous application for begonia, impatiens, petunia, and chrysanthemum, respectively. These ratios should serve as a guide

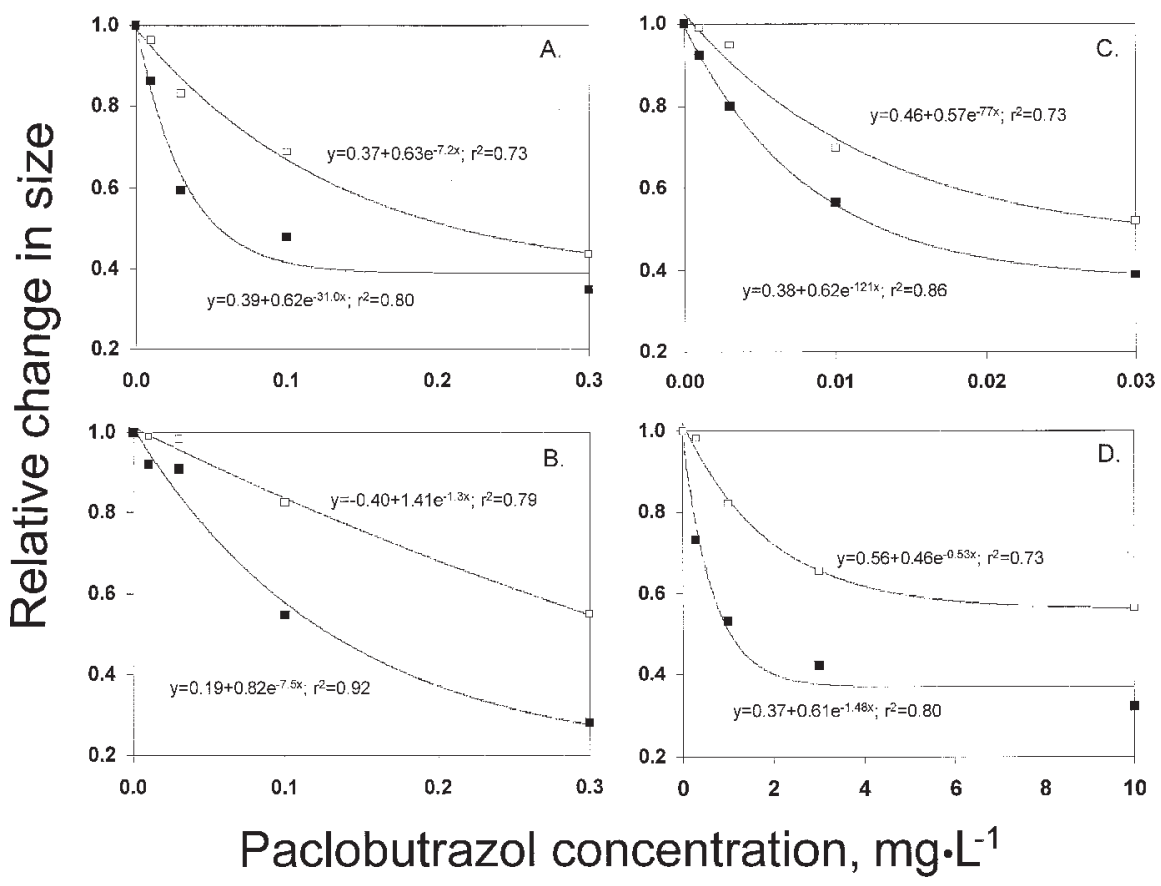

Fig. 1. Size control response of several flowering plants to the concentration of paclobutrazol applied once ( $\square$ ) or continuously $(\mathbf{\square})$ in subirrigation water: $(\mathbf{A})$ impatiens 'Super Elfin White'; (B) chrysanthemum 'Tara'; (C) begonia 'Cocktail Gin'; and (D) petunia 'Plum Crazy'. Symbols represent treatment means $(\mathrm{n}=18)$

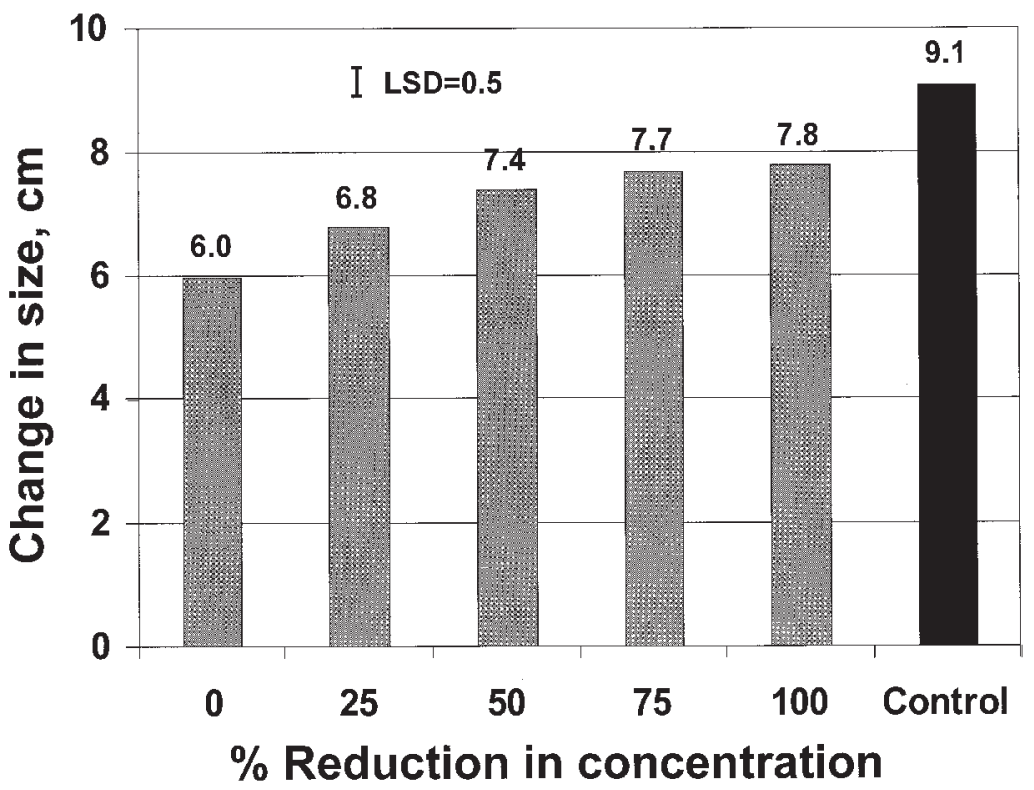

Fig. 2. Size control response of impatiens 'Super Elfin Salmon Blush' following the application of paclobutrazol at $0.1 \mathrm{mg} \cdot \mathrm{L}^{-1}$ in subirrigation water. Treatment reduction percentages represent the concentration reduction between successive subirrigations following the initial application. 
for the initial treatment application was 129 (7), $96(8), 74(10)$, and 92 (8) $\mathrm{mL} /$ pot for begonia, impatiens, chrysanthemum, and petunia, respectively. Based upon the uptake volumes, the amount of active ingredient that provided acceptable size control for one-time application of paclobutrazol in subirrigation solution was $0.0014,0.0084,0.014$, and 0.21 $\mathrm{mg} /$ pot. These application rates are lower than those typically used for drench applications. Further research is needed to determine how volume of solution taken up during subirrigation affects paclobutrazol efficacy. Also, inclusion of pine bark in media has been shown to reduce paclobutrazol efficacy (Million et al., 1998) and higher application rates would likely be required if applying paclobutrazol via subirrigation in bark-based media.

Expt. 2. Concentration reduction effect. Mean plant height, width, and size of the untreated control at the time of first treatment were 3,10 , and $7 \mathrm{~cm}$. At the end of the trial, respective values were 8,23 , and $16 \mathrm{~cm}$. Treated plants appeared normal and showed no signs of phytotoxicity due to paclobutrazol treatments.

A one-time application of paclobutrazol at $0.1 \mathrm{mg} \cdot \mathrm{L}^{-1}(100 \%$ reduction) resulted in a reduction in growth of $14 \%(7.8 \mathrm{vs} .9 .1 \mathrm{~cm})$
(Fig. 2). Continuous application at $0.1 \mathrm{mg} \cdot \mathrm{L}^{-1}$ ( $0 \%$ reduction) resulted in a reduction in growth of $34 \%(6.0$ vs. $9.1 \mathrm{~cm})$. The latter treatment caused slightly excessive growth control whereas the $25 \%$ reduction treatment gave more acceptable control $(25 \%$ reduction in growth) $(6.8 \mathrm{vs} .9 .1 \mathrm{~cm})$. There was little difference in growth of plants that received a single paclobutrazol application (100\% reduction) and those that received additional applications with concentrations that were reduced $50 \%$ or more between subsequent subirrigations. The results indicate that a grower could assume a one-time application effect even if there was residual chemical in the recycled irrigation solution as long as the grower knew that the residual paclobutrazol concentration was being reduced more than $50 \%$ before being used again on the same crop. The reduction rate seems to have a greater effect on paclobutrazol efficacy when the reduction rate is $<50 \%$. When this is the case, the optimal concentration is likely be intermediate to that observed for one-time and continuous applications. In commercial situations where the reduction rate is $<50 \%$, it will be more difficult to determine optimum concentrations and it may be best to apply the paclobutrazol continuously at a lower concentration.

\section{Literature Cited}

Adriansen, E. 1989. Growth and flowering in pot plants soaked with plant growth regulator solutions in ebb and flood benches. Acta Hort. 251:319-327.

Barrett, J.E. 1982. Chrysanthemum height control by ancymidol, PP333, and EL-500 dependent on medium composition. HortScience 17:737-738.

Barrett, J.E., and J.E. Erwin. 1994. Bedding plant height control, p. 197-213. In: E.J. Holcomb (ed.). Bedding plants IV: A manual on the culture of bedding plants as a greenhouse crop. $4^{\text {th }}$ Ed.

Little, T.M., and F.J. Hills. 1978. Agricultural experimentation: Design and analysis, p. 206. John Wiley and Sons.

Million, J.B., J.E. Barrett, T.A. Nell, and D.A. Clark. 1998. Influence of media components on efficacy of paclobutrazol in inhibiting growth of broccoli and petunia. HortScience 33:852-856.

Million, J.B., J.E. Barrett, T.A. Nell, and D.A. Clark. 1999. Inhibiting growth of flowering crops with ancymidol and paclobutrazol in subirrigation water. HortScience 34:1103-1105.

Newman, S.E. and J.S. Tant. 1995. Root-zone medium influences growth of poinsettias treated with paclobutrazol-impregnated spikes and drenches. HortScience 30:1403-1405.

Sanderson, K.C., W.C. Martin, Jr., and J. McGuire. 1988. Comparison of paclobutrazol tablets, drenches, gels, capsules, and sprays on chrysanthemum growth. HortScience 23:10081009. 